\title{
Erratum to: $\Delta \mathrm{Np} 63$ regulates cell proliferation, differentiation, adhesion, and migration in the BL2 subtype of basal-like breast cancer
}

\author{
Paulina Orzol $^{1}$ • Marta Nekulova ${ }^{1} \cdot$ Jitka Holcakova $^{1} \cdot$ Petr Muller $^{1} \cdot$ Borivoj Vojtesek $^{1}$. \\ Philip J. Coates ${ }^{1}$
}

Published online: 25 April 2016

(C) International Society of Oncology and BioMarkers (ISOBM) 2016

Erratum to: Tumor Biol.

DOI 10.1007/s13277-016-4880-x

In the original published online paper, the name of the fifth author was incorrectly captured.

The author name should have been Borivoj Vojtesek not Borivoj Votesek. The corrected author name is shown above.

The online version of the original article can be found at http://dx.doi.org/ 10.1007/s13277-016-4880-x.

\footnotetext{
Borivoj Vojtesek

vojtesek@mou.cz

$\triangle$ Philip J. Coates

philip.coates@mou.cz

1 Regional Centre of Applied and Molecular Oncology, Masaryk

Memorial Cancer Institute, Zluty kopec 7, 656

53 Brno, Czech Republic
} 